\title{
Strategic environmental assessment implementation of transport and mobility plans. The case of Italian regions and provinces
}

\author{
Andrea De Montis, ${ }^{1}$ Simone Caschili, ${ }^{2}$ Amedeo Ganciu, ${ }^{3}$ Antonio Ledda, ${ }^{1,4}$ Filippo Paoli, ${ }^{1}$ \\ Federico Puddu, ${ }^{1}$ Mario Barra' \\ ${ }^{1}$ Department of Agricultural Sciences, University of Sassari, Italy; ${ }^{2}$ LaSalle Investment \\ Management, London, UK; ${ }^{3}$ Department of Architecture and Planning, La Sapienza University, \\ Rome, Italy; ${ }^{4}$ Department of Civil and Environmental Engineering and Architecture, \\ University of Cagliari, Italy
}

\begin{abstract}
Transport and mobility plans imply strategies and actions that affect the environment. The European Union has introduced in 2001 the strategic environmental assessment (SEA) to take into account and mitigate adverse environmental effects in planning and decision-making. SEA limited implementation has attracted the interest of many scholars that have sought methods able to assess the quality of SEA processes by identifying vices and virtues in practice. In this paper, we measure the quality of eight SEAs for transport and mobility plans of regional and provincial administrations of Italy. Results show that the overall quality level of SEA reports is only barely sufficient, Abruzzo is among the virtuous and Piedmont among the critical administrations. We also stress that the determination of impact significance has received the worse quality score. We finally compare our results to other Italian and British homologous cases finding interesting and generally confirmative evidences.
\end{abstract}

Correspondence: Andrea De Montis, Department of Agricultural Sciences, University of Sassari, viale Italia 39, 07100 Sassari, Italy.

Tel.: +39.079.229242 - Fax: +39.079 .229243 .

E-mail: andreadm@uniss.it

Key words: Strategic environmental assessment; transport and mobility plans; quality review package, comparative analysis.

See online Appendix for additional Tables.

Received for publication: 29 September 2015.

Accepted for publication: 24 January 2016.

(C) Copyright A. De Montis et al., 2016

Licensee PAGEPress, Italy

Journal of Agricultural Engineering 2016; XLVII:513

doi:10.4081/jae.2016.513

This article is distributed under the terms of the Creative Commons Attribution Noncommercial License (by-nc 4.0) which permits any noncommercial use, distribution, and reproduction in any medium, provided the original author(s) and source are credited.

\section{Introduction}

Strategic environmental assessment (SEA) is a mandatory tool to ascertain the impacts of certain plans and programs over the environment. SEA is valuable as it integrates sustainability in decision making and planning. This procedure was introduced by the directive 2001/42/EC (hereinafter, Directive) (European Commission, 2001). In the panorama of the reception of the Directive by Member States, Italy published three legislative decrees: n. 152 in 2006, n. 4 in 2008, and n. 128 in 2010 (Italian Regulation, 2006, 2008, 2010). Furthermore, since the introduction of SEA the Italian planning practice has opened to a number of changes in order to tackle a number of critical issues, such as direct, indirect, and cumulative impact definition, public participation, alternative generation, and monitoring. As a consequence, many researchers have turned their attention to SEA implementation quality in a variety of sectors and administrative levels (De Montis, 2014, 2013).

Transport and mobility plans constitute a prominent and challenging sector of SEA application (Corpade et al., 2012). The design, construction, and management of infrastructures and the implementation of mobility policies interfere with the environment generating impacts that deserve specific analyses above the project level in planning and decision-making processes (Sheate, 1992). Nevertheless, there is still much work to do in order to fully integrate SEA in transport and mobility planning for a number of issues including public consultation and monitoring (Tomlinson, 2011). According to a number of scholars, SEA implementation quality depends on a series of concerns including general context, impact definition, and follow up (De Montis et al., 2014). In many cases, studies investigate SEA focusing on the SEA report, the most important document concerning the integration of environmental concerns into the approval procedure of a plan.

In this paper, we assess the quality of SEA reports developed in eight transport and mobility plans approved by regional and provincial administrations of Italy. We follow a methodology proposed by Fischer (2010) and modified by De Montis (2014) and designed to assess the effectiveness of the SEA reports with respect to a review package that includes questions regarding many relevant implementation issues. The argument unfolds as follows. In the next section, we introduce some reflections on SEA implementation for transport and mobility plans, present the methodology adopted for assessing the quality of SEA reports, describe the legislative context, and introduce the eight transport and mobility plans selected. In the subsequent section, we present and discuss the results of our analysis by comparing our results to other four homologous international cases. In the last section, we summarize and critically review the main findings of this paper. 


\section{Materials and methods}

\section{Strategic environmental assessment for transport and mobility plans}

The Directive has introduced SEA in Europe with a mandatory deadline of July 21, 2004 for the integration in the juridical systems of Member States (European Commission, 2001). The process of ratification has shown a great heterogeneity in time and procedures across Europe (De Montis, 2014; De Montis et al., 2014). Italy has approved the Legislative Decree n. 152 in 2006, also known as Environmental code (Italian Regulation, 2006). Because this act presented many pitfalls and interpretative doubts, the Italian State has later approved two legislative decrees - n. 4 in 2008 and n. 128 in 2010 (Italian Regulation, 2008, 2010) - which have clarified many issues and completed the reception of the Directive in Italy.

SEA introduction in planning processes implies not only a formal adherence to regulations but namely the attainment of a higher efficiency, with respect to environmental concerns, and an effective capacity to influence political decisions, deliberative actions, and plan approval and management (van Doren et al., 2013). In this respect, a good SEA process is based on a wide and open public participation (IAIA, 2002; Fischer and Gazzola, 2006; European Commission, 2009; Van Buuren and Nooteboom, 2010; Gauthier et al., 2011). According to Corpade et al. (2012), public participation enhances transparency of both SEA process and its results. According to many authors (Brokking et al., 2004; Diamantini and Geneletti, 2004; Corpade et al., 2012), SEA report is a fundamental document including: i) a description of relevant interactions of the plan under scrutiny with the environment; ii) an analysis of the status quo ante of the environmental components (biodiversity, population, health, soil, water, air, cultural heritage, landscape, etc.); iii) an evaluation of direct, indirect, cumulative and synergic impacts of the plan on the environment; iv) an indication of measures able to mitigate and compensate the impacts; and v) a prevision on the development of the monitoring phase. In transport planning, some regulations concerning the design of mobility infrastructures in areas not interested by agricultural production and soil protection are specifically addressed to the mitigation of negative impacts (European Commission, 2001; Corpade et al., 2012).

The White Paper on the future development of the common transport policy is one of the earliest documents released by the European Commission that takes into consideration the relationships between transport planning and environmental impacts (European Commission, 1992). In this respect, according to Decision No 884/2004/EC amending Decision No 1692/96/EC on Community guidelines for the development of the trans-European transport network (European Commission, 2004), projects of new transport infrastructures are subject to the environmental impact assessment (EIA) procedure introduced by Directive 1985/337/EEC (European Commission, $1985)$ while plans and programs above those projects must conform to the SEA procedure. The European Commission $(1999,2005)$ has released specific guidelines concerning SEA implementation in transport planning and designed to: i) prevent the environmental impacts and delays in transport infrastructure implementation; ii) exclude highly impacting alternatives, which would imply very expensive mitigation measures; iii) prevent social conflicts, generated by the implementation of transport plans, by improving environmental public awareness and by directly and indirectly involving citizens.

According to many authors (Brokking et al., 2004; Fischer, 2006; Corpade et al., 2012), the assessment of environmental effects brought by a new transport infrastructure should develop through different decisional tiers. First, SEA should be implemented on transport policies, plans and programs and provide the framework for succeeding EIA procedures of programmed transport projects (Diamantini and Geneletti, 2004).

In Table 1, we outline the tiers of environmental assessment of the many documents leading to the design and realization of transport infrastructures. At the high level, SEA is used to focus on the valuation of transport European, national or local policies, according to a multisector approach involving economic, social, and transport themes. At the Intermediate level, plans and programs are subject to SEA with a finer attention to mobility demand and transport means choice. At the low level, projects of transport infrastructures are evaluated through EIA procedure, where specific local, environmental, social, and economic costs and benefits are investigated.

According to Sheate (1992), SEA is useful especially for the analysis of long-term policies, as it allows planners to choose knowingly by taking into account in a harmonic perspective the interaction between mobility and transport strategies and environmental and landscape components.

Central element in SEA implementation for transport and mobility planning is a correct definition of the environmental objectives. The attainment of those objectives should be assessed through quali-quantitative measures and thresholds (Sheate, 1992).

As reported in Table 2, several authors have studied environmental objectives of SEAs developed for national transport plans in Europe (Sheate, 1992; Fischer, 1999, 2006; Jansson, 1999; Brokking et al., 2004; Diamantini and Geneletti, 2004; Hildén et al., 2004; European Commission, 2005; Corpade et al., 2012; Finnveden and Åkerman, 2014).

According to Brokking et al. (2004), Sweden has taken into account environmental effects of transport plans since the 1990s, when a very similar procedure was developed even before the approval of the Directive. Brokking et al. (2004) observe that although this procedure was ground-breaking in Europe, it was usually activated in the last stages of the approval process of a plan thus too late for a correct analysis of the environmental concerns. Diamantini and Geneletti (2004) have analysed SEA implementation of the mobility plan approved by the autonomous province of Trento, Italy. They found that the SEA process was based on speculations instead of quail-quantitative analyses. Fischer (2006) has proposed a framework for the assessment of SEA implementation for transport and mobility plans in the United Kingdom. This framework includes descriptive and quantitative measures and constitutes the starting point for drafting guidelines on SEA implementation in the transport sector. In the next section, we present some methods able to assess the quality of SEA implementation.

Table 1. The different tiers in environmental assessment: focus, tool, and key concepts.

\begin{tabular}{|c|c|c|c|}
\hline Decisional level & Focus & Tool & Key concepts \\
\hline High & Policies & SEA & Interplay between transport and environment, economics, industrial development, etc. \\
\hline Intermediate & Plans, Programs & SEA & Mobility demand and analysis of transport infrastructures and corridors \\
\hline Low & Projects & EIA & Economic and environmental costs and benefits of transport infrastructures \\
\hline
\end{tabular}

SEA, strategic environmental assessment; EIA, environmental impact assessment. 


\section{Measuring the efficiency of strategic environmental assessment: methodological issues}

Scientific literature on SEA, in general, and on SEA effectiveness, in particular, is very rich. Some authors have scrutinized quali-quantitative indicators for measuring SEA effectiveness. Fischer and Gazzola (2006) propose two groups of criteria for the Italian SEA practice: the first one regards institutional and participative procedures; the second one reliability and control of focussed, iterative, flexible and informed processes. Jiricka and Pröbstl (2008) study SEA implementation on municipal master planning in Alpine states interviewing the public officials involved. They focus on the following SEA stages: screening, scoping, environmental report, consultation, and follow-up. Noble (2009) examines the Canadian SEA system adopting 15 criteria grouped into three areas under these concepts: SEA system, process, and outcomes. De Montis (2013) studies SEA implementation within provincial strategic spatial planning in Italy by developing two questionnaires about general and special aspects.

The quality review package (QRP) of SEA report has been completed by five academic experts in the field (Appendix Table 1). The grading system is based on a quantitative lettered scale from A to $\mathrm{G}$ that has been translated in quantitative terms according to a scheme proposed by De Montis (2014) and Fischer (2010) and reported in Appendix Table 2.

The QRP of SEA report has been applied so far in a variety of contexts. Fischer (2010) studied SEA report quality of 117 municipal spatial plans in the UK. Fischer et al. (2011) applied the QRP to twenty-five municipal water management plans in the UK. Fischer (2012) applied the same methodology to the assessment of seven local transport plans in the UK. Finally, De Montis (2014) applied a modified release of the QRP of SEA report to measure the performance of eight energy plans in Italy.

\section{Selection of eight transport and mobility plans in Italy}

In Italy, the central government has devolved to regional administrations and local bodies the approval of local transport and mobility plans (Osservatorio Città Sostenibili, 2014). In the Italian planning system, the regional transport and mobility plan (RTMP) is the main instrument directed to the definition of public transport policies.

RTMPs' drafting and management obey the principles of current juridical regulations including law n. 151 approved in 1981 (Italian Regulation, 1981) and Legislative Degree (LD) n. 422 approved in 1997 (Italian Regulation, 1997) (Table 3).

Guidelines for the design and management of RTMPs have been indicated at the national level in the general plan of transport and logistic (GPTL) approved in 2001 (Italian Regulation, 2001). The GPTL indicates objectives, constraints, methodologies, and strategies for transport planning over regional administrations and specifies that RTMPs should not be conceived as mere summation of infrastructure designs, but as a systematic plan aiming at integrating a variety of transport modalities and encouraging modalities that lead to lower environmental impacts.

We selected a set of eight RTMPs (Table 4) recently designed and approved according to SEA regulations. We chose those plans that local administrations provided with a complete documentation (including SEA reports) in their institutional websites. Information was collected between May and June 2014.

The SEA sample regards local administrations for an area of about 125,800 square $\mathrm{km}$ (roughly $40 \%$ of the total extension of Italy) and about 27 million people (about $45 \%$ of the total Italian population as of December 31, 2013). In Figure 1, we illustrate the geographical location of the administrations involved.

Following a scheme proposed by De Montis (2014) for the analysis of SEA reports of energy plans, in Table 5 we report on the SEA reports of

Table 2. Environmental objectives of national transport plans in Europe.

\begin{tabular}{|c|c|}
\hline State & Environmental objectives \\
\hline Finland & $\begin{array}{l}\text { Reduction of transport demand, increase of sustainable mobility, reduction of negative effects of transport on the environment } \\
\text { Maintain GHG emissions at } 1990 \text { 's level } \\
\text { Reduction of NOx emissions } \\
\text { Reduction of PM10 emissions and risks over health } \\
\text { Prevent new forms of traffic pollution and reduction of citizens' exposure to dangerous substances } \\
\text { Reduction of population living in noisy ( }>55 \mathrm{~dB} \text { ) areas } \\
\text { Rational use of natural resources by containing land use } \\
\text { Defence of natural resources (soil, air, water, etc.) preventing their pollution } \\
\text { Preservation of biodiversity }\end{array}$ \\
\hline United Kingdom & $\begin{array}{l}\text { Preservation of natural resources minimizing negative impacts over the environment } \\
\text { Reduction of pollution in superficial and ground waters } \\
\text { Reduction of population exposure to pollution and increase quality of life }\end{array}$ \\
\hline Austria & $\begin{array}{l}\text { Reduction of GHG emission, energy consumption, and air pollution } \\
\text { Reduction of land use } \\
\text { Reduction of the impact over protected areas } \\
\text { Reduction of the impact over recreational areas } \\
\text { Annulment the risk of pollution of water resources } \\
\text { Reduction of impacts over landscape and diminution of the fragmentation }\end{array}$ \\
\hline Germany & $\begin{array}{l}\text { Reduction of transport costs } \\
\text { Reduction of transport time } \\
\text { Increase of transport security } \\
\text { Increase of infrastructure level } \\
\text { Increase of environmental quality } \\
\text { Protection of natural resources and landscape }\end{array}$ \\
\hline
\end{tabular}

GHG, greenhouse gas. 
transport and mobility plans with respect to the following characteristics. Year refers to the date of approval or adoption of the SEA report. Objectives concerns the aims declared in that document. SEA regulation stands for the law ruling the procedure. SEA process informs on the proposed technical procedure, Landscape and environmental analysis on the ecological components considered, and Environmental assessment method on the most relevant tools adopted in the study. Alternatives section verifies the correct development and assessment of different alternative scenarios, and Mitigation strategies refers to the explanation of suitable actions for diminishing the impacts over the environment. Finally Consultation concerns the description of the measures developed for encouraging experts' and public participation, and Follow up the illustration of the monitoring system and report for assessing the impact of plans over time.

The eight RTMPs have been recently approved as the dates of approval always fall in the 2010s. The most recent one has been approved by Lombardy region (2014). RTMPs' objectives range from the development of transport infrastructure (for Abruzzo and Friuli Venezia Giulia) to sustainable mobility (for Lombardy) and the enhancement of accessibility (for Emilia Romagna). Each local administration has developed the SEA process according to a specific regional law. In some cases (see Emilia Romagna and Lombardy), these laws rule SEA processes of plans and programs belonging to various sectors including spatial and land use planning. The SEA reports describe a variety of processes involving SEA prescribed phases, such as description of context, impact assessment, generation and analysis of the alternatives, description of mitigation strategies, monitoring, and follow up. The emphasis of SEA reports is mostly directed to the analysis of environmental components (air, water, soil), while some cases (Friuli Venezia Giulia) develop on the impact over landscapes and cultural heritage. The methodologies adopted for the assessment of environmental impacts are often based on indicators drawn from international guidelines (Abruzzo) and actions/components matrices (Emilia Romagna, Lombardy, and Trento). The authors of the SEA reports have directed the study to the assessment of at least two alternative scenarios, with

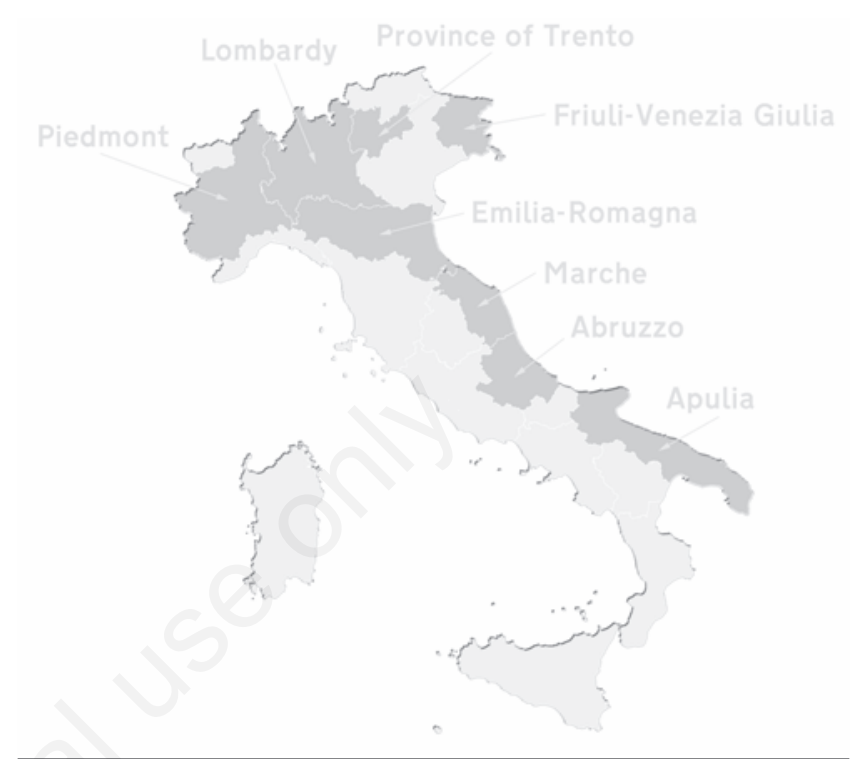

Figure 1. Location of the local administrations included in this study.

Table 3. Italian regulation of regional transport planning.

\begin{tabular}{|c|c|}
\hline Act & Tasks of regional administrations \\
\hline Law n. 151/1981 & $\begin{array}{l}\text { i) Definition of regional transport and mobility policy according to the National Transport General Plan } \\
\text { ii) Design of RTMP according to spatial and regional development principles } \\
\text { iii) Adoption of long term programs of investment and local public transport management }\end{array}$ \\
\hline LD 422/1997 & $\begin{array}{l}\text { i) Definition of guidelines for local transport planning and in particular for Provincial Transport Plans } \\
\text { ii) Design and update Regional Transport Plans taking into account the needs of local administrative bodies } \\
\text { (provinces, metropolitan areas, etc.), and other sector plans } \\
\text { iii) Creation of a mobility network based on the integration of various transport modalities and on the diminution of environmental impact }\end{array}$ \\
\hline
\end{tabular}

Table 4. Selected regional transport plans by administration and denomination.

\begin{tabular}{|c|c|c|}
\hline $\begin{array}{l}\text { Public administrat } \\
\text { Region }\end{array}$ & Autonomous province & Denomination in Italian (and in English) \\
\hline Abruzzo & & Piano regionale integrato dei trasporti (Regional transport integrated plan) \\
\hline Apulia & & Piano regionale dei trasporti piano attuativo 2009-2013 (Regional transport detailed plan) \\
\hline Emilia Romagna & & Piano regionale integrato dei trasporti - PRIT2020 (Regional transport integrated plan) \\
\hline Friuli Venezia Giulia & & $\begin{array}{l}\text { Piano regionale delle infrastrutture di trasporto, della mobilità delle merci e della logistica } \\
\text { (Regional plan of transport infrastructure, mobility, freight, and logistics) }\end{array}$ \\
\hline Lombardy & & Piano regionale della mobilità ciclistica (Regional cycling mobility Plan) \\
\hline Marche & & Piano Regionale del trasporto pubblico locale (Regional local public transport plan) 2009-2019 \\
\hline Piedmont & Trento & $\begin{array}{l}\text { Piano regionale per la logistica (Regional plan of logistics) } \\
\text { Piano stralcio della mobilità collegamento San Martino di Castrozza - Passo Rolle } \\
\text { (San Martino di Castrozza - Passo Rolle mobility plan) }\end{array}$ \\
\hline
\end{tabular}




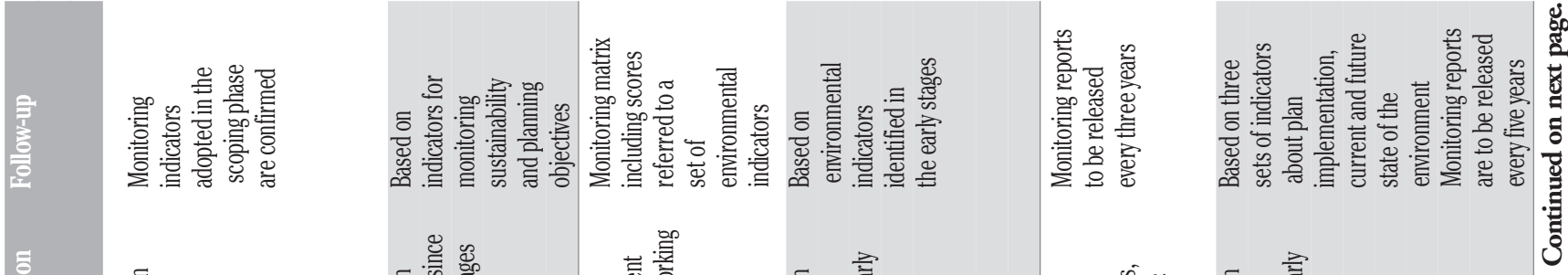

In⿴囗十 III

In IIn

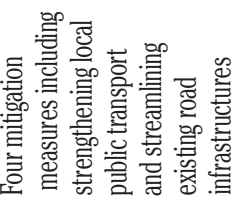

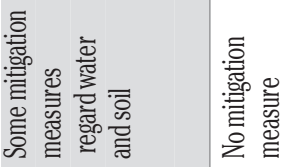

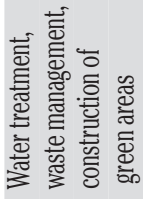

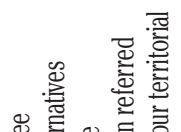

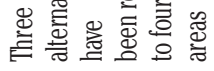

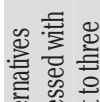

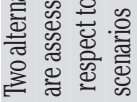

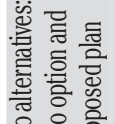

롤 웠 흘

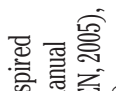

कํㅡㄹ 출영

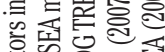

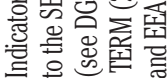

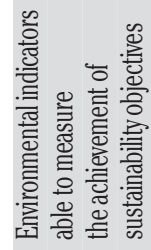

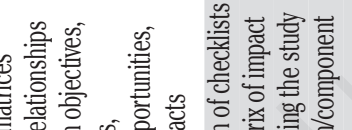

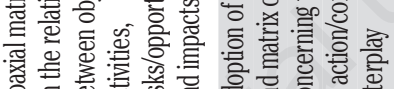

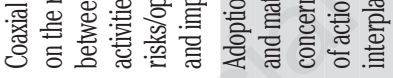

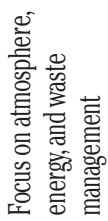

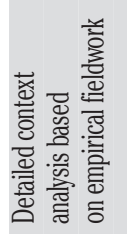

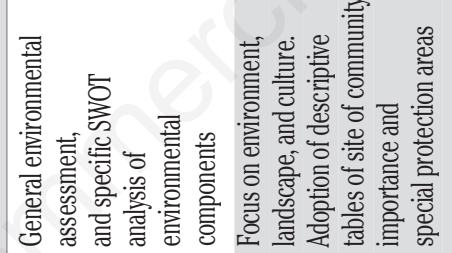

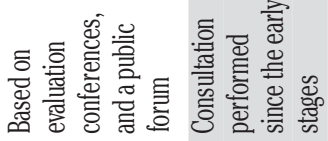

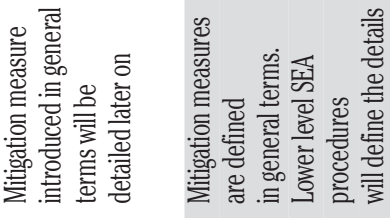

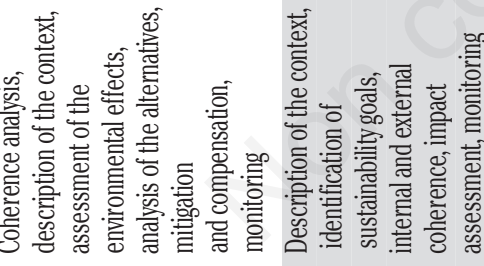

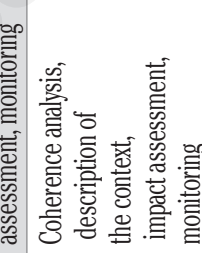

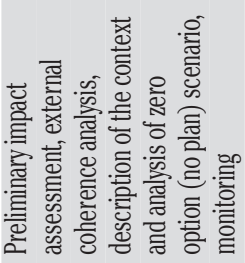

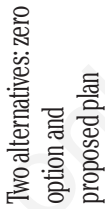

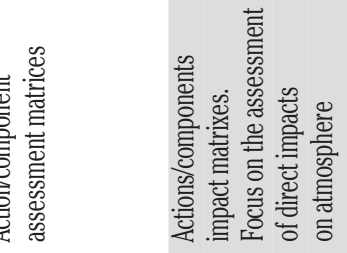

每

言

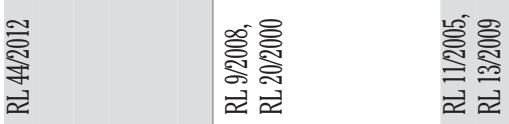

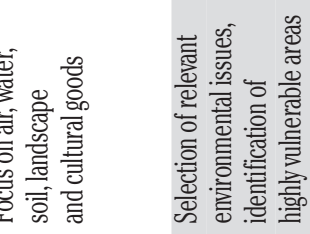

逆

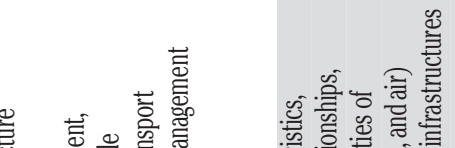

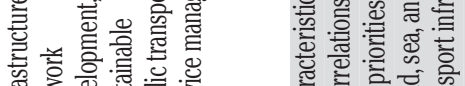

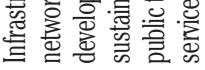

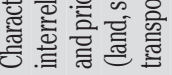

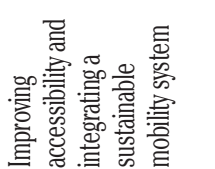

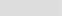

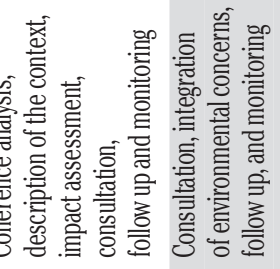
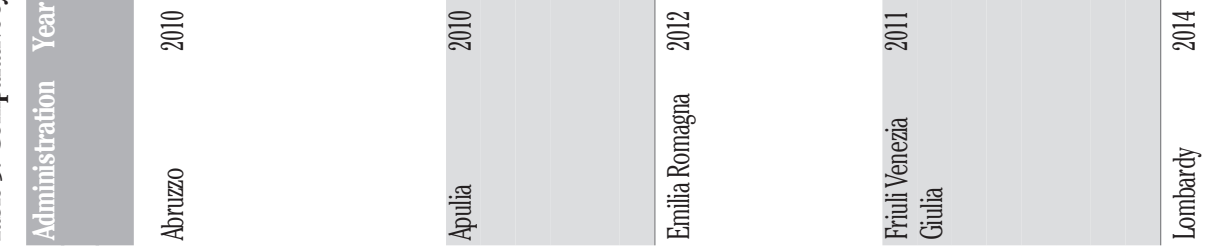

产

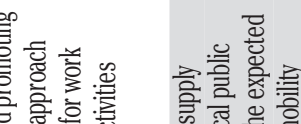




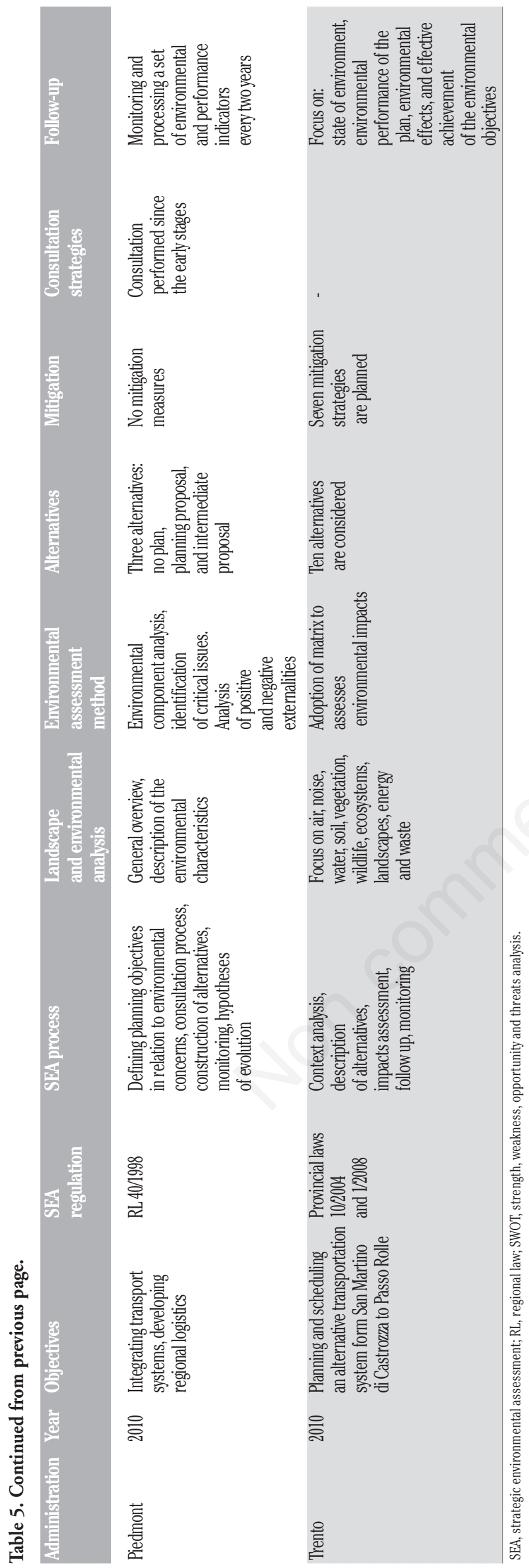

the exception of Emilia Romagna and Marche (no alternatives). In some cases (Abruzzo, Apulia) alternatives have been referred to different geographical areas or scenarios. With the exception of Emilia Romagna and Piedmont, SEA reports indicate mitigations strategies in either general or specific terms. Abruzzo proposes streamlining existing road infrastructure, while Friuli Venezia Giulia the construction of green areas. Consultation has often been activated since the early stages of planning processes (Abruzzo, Apulia, Friuli Venezia Giulia, Marche). Piedmont and Trento have not led any public participation. Monitoring and follow up are prominent activities that have always been developed. In some cases, monitoring has involved the adoption of environmental indicators selected since the scoping phase (Abruzzo, Friuli Venezia Giulia). In some other cases (Lombardy, Marche, Piedmont) SEA reports focus on the opportunity to release periodically monitoring reports (Provincia Autonoma di Trento, 2004, 2008, 2010; Regione Abruzzo, 2006, 2010; Regione Emilia Romagna, 2000, 2008, 2012; Regione Friuli Venezia Giulia, 2005, 2009, 2011; Regione Lombardia, 2005, 2014; Regione Marche, 2007, 2011; Regione Piemonte, 1998, 2010; Regione Puglia, 2010, 2012).

\section{Results}

This section focuses on the results of the application of the QRP of SEA reports introduced in section 3 of Appendix Table 2. In Table 6, we present the scores of each question of the package for each RTMP. The average score (5.90) indicates that the quality level of the eight SEA reports is barely sufficient. This value originates from figures ranging from discrete scores (higher than 7) attributed to Abruzzo, Apulia, Friuli Venezia Giulia, and Lombardy, to poor scores (lower than 5) assigned to Piedmont and Trento. The average scores of sections 1 and 2 (premises of SEA report) have values well above the sufficiency level, while the other sections are evaluated well below the sufficiency level (see the case of section 3 regarding the determination of impact significance).

The scrutiny of the scores by section provides the reader with a more precise picture. Section 1 has a discrete performance (average score of 7.20), which originates from a good description of environmental concerns and sustainability objectives (Abruzzo and Friuli Venezia Giulia). The average score reported for section 2 (identification and evaluation of key issues/options) is above the sufficiency level (6.57). Abruzzo's report excels among all the other reports, while the other administrations show a lower attention to the alternatives' definition. Marche has been assigned the lowest score in both sections 1 and 2 .

The average score of section 3 (determination of impact significance) is below the sufficiency level (4.91). Questions 21, 22, and 23 concerning, inter alia, duration, frequency, reversibility, synergistic nature of the effects on the environment have received the lowest scores (on average, slightly above 3). With the exception of Friuli Venezia Giulia, the SEA reports do not take into account trans-frontal impacts properly. The consultation process (section 4) has not received a sufficient attention (the average score is slightly below the sufficiency threshold, 5.50). Unexpectedly Emilia Romagna, Piedmont and Trento do not pay a sufficient consideration for public consultation albeit their reputation. These performances are partly balanced by the high scores received by Friuli Venezia Giulia, Lombardy, and Marche. Unsurprisingly the presentation of information and results (section 5) is also slightly less than sufficient (5.48). The overall scores' range is remarkable: Marche scores well, while Emilia Romagna and especially Piedmont do much worse. The most critical concerns are on average for question 33 regarding the provision of information on any difficulties and uncertainties encountered in compiling the required information. 
In the same way, the average score for section 6 (recommendations on preferred options and monitoring) is slightly below the sufficiency level (5.48). The lowest average score has been assigned to question 39 concerning the maximization of the beneficial effects. In this respect, Abruzzo and Apulia both received 7; Piedmont and Trento only 2 and 1.

In Figure 2, we use a spider graph to illustrate the results of the analysis of the average scores obtained for each of the six sections of the QRP of the SEA reports. The disposition of the lines allows to immediately detecting strengths and weaknesses: sections 1 and 2 receive fairly good scores, while section 3 much lower values. In addition, the extension of the area bounded by the lines is proportional to the overall score attributed to each section in the QRP.

\section{Discussion}

This section reviews the results that we have obtained from the application of the QRP with the aim to detect strengths and weaknesses of SEA practice for transport and mobility plans. In addition, because the methodology that we have applied has been put into practice in other sectors and countries, we compare the results obtained in this paper with those elaborated by other scholars for Italian energy plans, British spatial plans, local transport plans (LTP), and municipal waste management plans (MWMP) (Fischer, 2010; Fischer et al., 2011; Fischer, 2012; De Montis, 2014).

Table 6. Quality review package results of the eight strategic environmental assessment reports.

\begin{tabular}{|c|c|c|c|c|c|c|c|c|c|c|c|}
\hline & Questions & Abruzzo & Apulia & Emilia Romagna & $\begin{array}{l}\text { Administrations } \\
\text { Friuli Veneria Giulia }\end{array}$ & Lombardy & Marche & Piedmont & $\begin{array}{l}\text { Average } \\
\text { t Trento }\end{array}$ & $\begin{array}{l}\text { alues } \\
\text { Questions }\end{array}$ & Section \\
\hline 1 & $\begin{array}{c}1 \\
2 \\
3 \\
4 \\
5 \\
6 \\
7 \\
8 \\
9 \\
10\end{array}$ & $\begin{array}{l}10 \\
10 \\
7 \\
6 \\
10 \\
10 \\
10 \\
10 \\
10 \\
9\end{array}$ & $\begin{array}{l}10 \\
10 \\
10 \\
10 \\
10 \\
10 \\
6 \\
8 \\
8 \\
9\end{array}$ & $\begin{array}{l}10 \\
10 \\
5 \\
5 \\
10 \\
6 \\
6 \\
8 \\
8 \\
7\end{array}$ & $\begin{array}{c}10 \\
10 \\
9 \\
9 \\
10 \\
10 \\
10 \\
10 \\
6 \\
9\end{array}$ & $\begin{array}{c}10 \\
8 \\
7 \\
7 \\
10 \\
7 \\
10 \\
10 \\
6 \\
8\end{array}$ & $\begin{array}{c}7 \\
7 \\
4 \\
4 \\
8 \\
1 \\
10 \\
6 \\
1 \\
5\end{array}$ & $\begin{array}{l}6 \\
4 \\
3 \\
3 \\
6 \\
6 \\
4 \\
8 \\
2 \\
4\end{array}$ & $\begin{array}{l}9 \\
7 \\
3 \\
1 \\
7 \\
8 \\
8 \\
7 \\
7 \\
6\end{array}$ & $\begin{array}{l}8.86 \\
8.00 \\
5,86 \\
5.57 \\
8.71 \\
6.86 \\
7.71 \\
8.14 \\
5.43 \\
6.86\end{array}$ & 7.20 \\
\hline 2 & $\begin{array}{l}11 \\
12 \\
13 \\
14 \\
15 \\
16 \\
17 \\
18\end{array}$ & $\begin{array}{l}10 \\
10 \\
10 \\
10 \\
10 \\
10 \\
10 \\
10\end{array}$ & $\begin{array}{c}8 \\
8 \\
8 \\
10 \\
8 \\
10 \\
8 \\
8\end{array}$ & $\begin{array}{c}8 \\
10 \\
8 \\
6 \\
8 \\
6 \\
6 \\
7\end{array}$ & $\begin{array}{c}6 \\
10 \\
6 \\
8 \\
7 \\
4 \\
8 \\
7\end{array}$ & $\begin{array}{l}8 \\
8 \\
6 \\
9 \\
8 \\
6 \\
7 \\
7\end{array}$ & $\begin{array}{c}1 \\
10 \\
10 \\
1 \\
1 \\
5 \\
1 \\
4\end{array}$ & $\begin{array}{c}8 \\
10 \\
6 \\
5 \\
2 \\
8 \\
5 \\
6\end{array}$ & $\begin{array}{l}7 \\
7 \\
6 \\
7 \\
6 \\
1 \\
4 \\
5\end{array}$ & $\begin{array}{l}6.57 \\
9.00 \\
7.14 \\
6.57 \\
5.71 \\
5.71 \\
5.57 \\
6.29\end{array}$ & 6.57 \\
\hline 3 & $\begin{array}{l}19 \\
20 \\
21 \\
22 \\
23 \\
24 \\
25 \\
26\end{array}$ & $\begin{array}{l}7 \\
7 \\
6 \\
7 \\
2 \\
7 \\
7 \\
6\end{array}$ & $\begin{array}{l}8 \\
8 \\
6 \\
2 \\
2 \\
6 \\
8 \\
5\end{array}$ & $\begin{array}{l}6 \\
6 \\
5 \\
6 \\
2 \\
6 \\
6 \\
5\end{array}$ & $\begin{array}{l}9 \\
8 \\
2 \\
3 \\
8 \\
8 \\
7 \\
6\end{array}$ & $\begin{array}{l}8 \\
8 \\
3 \\
7 \\
5 \\
9 \\
7 \\
6\end{array}$ & $\begin{array}{c}6 \\
10 \\
1 \\
3 \\
1 \\
1 \\
1 \\
3\end{array}$ & $\begin{array}{l}8 \\
8 \\
3 \\
3 \\
2 \\
2 \\
2 \\
4\end{array}$ & $\begin{array}{l}4 \\
5 \\
3 \\
1 \\
1 \\
3 \\
6 \\
3\end{array}$ & $\begin{array}{l}7.00 \\
7.57 \\
3.29 \\
3.57 \\
3.00 \\
5.00 \\
5.29 \\
4.57\end{array}$ & 4.91 \\
\hline 4 & $\begin{array}{l}27 \\
28 \\
29 \\
30\end{array}$ & $\begin{array}{l}6 \\
6 \\
5 \\
5\end{array}$ & $\begin{array}{c}8 \\
10 \\
2 \\
6\end{array}$ & $\begin{array}{l}2 \\
2 \\
2 \\
2 \\
\end{array}$ & $\begin{array}{c}7 \\
10 \\
9 \\
8\end{array}$ & $\begin{array}{l}8 \\
7 \\
9 \\
8\end{array}$ & $\begin{array}{l}10 \\
10 \\
10 \\
10\end{array}$ & $\begin{array}{l}2 \\
4 \\
2 \\
2 \\
\end{array}$ & $\begin{array}{l}1 \\
1 \\
1 \\
1\end{array}$ & $\begin{array}{l}5.43 \\
6.29 \\
5.00 \\
5.29\end{array}$ & 5.50 \\
\hline 5 & $\begin{array}{l}31 \\
32 \\
33 \\
34 \\
35\end{array}$ & $\begin{array}{l}10 \\
7 \\
6 \\
2 \\
6\end{array}$ & $\begin{array}{l}6 \\
6 \\
6 \\
2 \\
5\end{array}$ & $\begin{array}{l}6 \\
5 \\
5 \\
2 \\
4\end{array}$ & $\begin{array}{l}7 \\
7 \\
2 \\
8 \\
6\end{array}$ & $\begin{array}{c}8 \\
9 \\
2 \\
10 \\
7\end{array}$ & $\begin{array}{c}8 \\
10 \\
10 \\
10 \\
9\end{array}$ & $\begin{array}{l}2 \\
4 \\
2 \\
2 \\
2\end{array}$ & $\begin{array}{l}7 \\
6 \\
9 \\
1 \\
5\end{array}$ & $\begin{array}{l}6.29 \\
6.71 \\
5.14 \\
5.00 \\
5.43\end{array}$ & 5.71 \\
\hline 6 & $\begin{array}{l}36 \\
37 \\
38 \\
39 \\
40 \\
41\end{array}$ & $\begin{array}{l}7 \\
7 \\
7 \\
7 \\
6 \\
6\end{array}$ & $\begin{array}{c}7 \\
6 \\
10 \\
7 \\
6 \\
7\end{array}$ & $\begin{array}{l}5 \\
5 \\
7 \\
6 \\
6 \\
5\end{array}$ & $\begin{array}{l}7 \\
8 \\
8 \\
6 \\
9 \\
7\end{array}$ & $\begin{array}{l}8 \\
8 \\
9 \\
6 \\
9 \\
8\end{array}$ & $\begin{array}{l}1 \\
1 \\
6 \\
5 \\
6 \\
3\end{array}$ & $\begin{array}{l}2 \\
2 \\
2 \\
2 \\
2 \\
2\end{array}$ & $\begin{array}{l}6 \\
6 \\
5 \\
1 \\
4 \\
4\end{array}$ & $\begin{array}{l}5.14 \\
5.14 \\
6.71 \\
4.71 \\
6.00 \\
5.14\end{array}$ & 5.48 \\
\hline & Average values & 7.66 & 7.27 & 5.85 & 7.54 & 7.59 & 5.39 & 3.95 & 4.63 & & 5.90 \\
\hline
\end{tabular}


Table 7. Comparison of strategic environmental assessment report quality review package results obtained in a variety of cases.

\begin{tabular}{|c|c|c|c|c|c|c|}
\hline Section & Key word & $\begin{array}{l}\text { Sector plan and country } \\
\text { TMP, Italy }\end{array}$ & EP, Italy & SP, UK & LTP, UK & MWMP, UK \\
\hline 1 & Baseline & $*$ & $* *$ & $*$ & $*$ & $* *$ \\
\hline 2 & Evaluation & $*$ & $*$ & $*$ & $* *$ & $* *$ \\
\hline 3 & Significance & $* * *$ & $* * *$ & $* * *$ & $* * *$ & $* * *$ \\
\hline 4 & Consultation & $* *$ & $* *$ & $* *$ & $* * *$ & $* *$ \\
\hline 5 & Presentation & $* *$ & $* *$ & $* *$ & $* * *$ & $* *$ \\
\hline 6 & Recommendation & $* *$ & $* * *$ & $* * *$ & $* * *$ & $* *$ \\
\hline
\end{tabular}

from Fischer, 2010, 2012; Fischer et al., 2011; De Montis, 2014.

Concerning the first issue, the analysis of the average values of the scores reported in Table 6 indicates that the first two sections concerning the premises of the SEA report receive judgments well above the sufficiency level. Section 3 on the determination of impact significance receives the worst scores, while sections 4,5 , and 6 show barely sufficient average scores.

Secondly, we provide the reader with an overview of the average scores reported in each section of five cases where the QRP of SEA reports has been applied (Table 7). We adopt a qualitative scoring system able to convey synthetic information on the average scores with respect to the sufficiency level.

The results obtained in this paper are similar to those of the other four cases listed in Table 7 . With the exception of baseline and evaluation analyses (sections 1 and 2), the remaining sections receive barely sufficient or worse average scores. In every case study, the worst average scores - below the sufficiency level - are associated to section 3 , where SEA reports define, assess and measure the significance of impacts generated by plans over the environment. This is quite a disappointing evidence, as impact evaluation, by definition, constitutes the core of SEA procedures. In particular, SEA report quality level proves insufficient with respect to the definition and measurement of synergic and cumulative effects of impacts occurring simultaneously on the same environmental systems, and of trans-frontal consequences of impacts acting on the environment of a given administration. Average scores for section 1 are above the sufficiency level in three cases and are just on that level for the remaining two cases. The same happens for section 2 but for a different set of plans. The consultation stage (section 4) has been judged as barely sufficient for all the cases with the exception of LTP in the UK, that has been evaluated as insufficient. The presentation of the results and information about the SEA process (section 5) follows the same outline of section 4: with the exception of LTP, in the UK, for all the remaining four cases they are barely sufficient. The last section 6 on final recommendation for decision-making is the second worst section of the package. In three cases, the average scores signal an insufficient attention to the final stage of SEA integration in the planning process.

\section{Conclusions}

In this paper we have studied SEA implementation in the sector of transport and mobility plans focusing on the quality of SEA reports. To assess the quality of SEA implementation we have adopted a method, i.e., the Sea report $\mathrm{QRP}$, that has allowed us to indicate strengths and weaknesses of SEAs in an international comparative perspective. We have selected eight SEA reports of transport and mobility plans approved by regional and provincial Italian administrations. After a

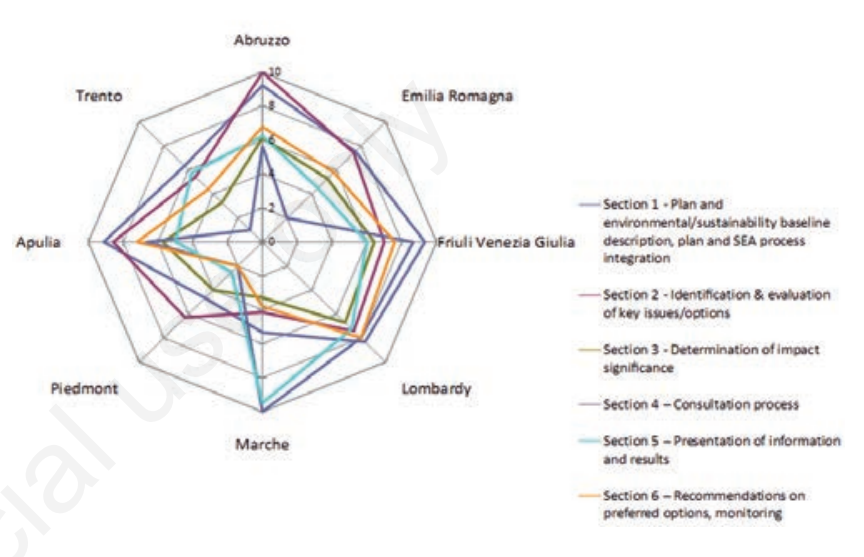

Figure 2. Spider graph representation of the average scores reported by the transport and mobility plans selected in each section. SEA, strategic environmental assessment.

qualitative description of the main characteristics emerging from the sampled SEA processes, we have assessed the SEA reports' quality and found results that generally confirm vices and virtues reported in other Italian and British homologous cases.

Results clearly show that the quality level of SEA reports of Italian transport and mobility plans is barely sufficient (average score is equal to 5.90). Abruzzo, Apulia, Friuli Venezia Giulia, and Lombardy have developed discrete SEA reports, while Piedmont and Trento much worse ones. An analysis of the average values by section points out that only sections 1 (on baseline premises) and 2 (about evaluation) are attributed values well above the sufficiency level. The other four sections are scored below the sufficiency level. Section 3 on the determination of impact significance is the most critical. A quite remarkable evidence, as the identification and assessment of impacts is at the heart of any environmental assessment exercise.

The comparison of our analysis with those of other studies broadly confirms that the results obtained in this study have a general value. Sections 1 and 2 about the preliminaries - i.e. baseline and evaluation analyses - represent generally virtuous aspects. The remaining sections are graded with barely sufficient or worse average scores. The worst average scores are again attributed to section 3, where SEA reports define, assess and measure the significance of impacts generated by plans over the environment.

The results of our study can be extended and become general statements on SEA report quality measured by section. In this respect, we 
stress that SEA implementation in various sector plans is multifaceted. A first issue regards the variety of bodies in charge of sector plans including regional, provincial, and municipal administrations, which have sometimes completely different institutional frameworks and procedures. Regional administrations address broad strategies over usually wide areas, while municipal bodies are responsible of detailed and operative plans concerning specific actions, areas and communities. A second concern attains the variability of time span spent to develop SEA procedures that ranges from some months for MWMPs to several years for spatial plans or regional energy plans. SEA implementation is time consuming: processes lasting longer may have better chances to achieve a higher quality level. A third issue regards the variability in the number of questions included in the different applications of the QRP of SEA reports (minimum 38 for LTPs and maximum 55 for MWMPs). A fourth concern attains the subjectivity - typical of qualitative inputs - in the attribution of the scores expressed by different panels of experts belonging to a variety of technical and cultural contexts. With respect to subjectivity management, a sensitivity-driven analysis of the interviewees may reduce the outcomes' variability by linking it to interviewees' skills, such as previous institutional involvement in SEA processes, competence and training in SEA theory and practice. In future studies, we will focus on the solution of these critical issues in the perspective of more efficient applications of the QRP of SEA reports.

\section{References}

Brokking P., Schmidtbauer J.C., Eriksson I.M., Balfors B. 2004. SEA in Swedish transportation policy-making and planning - political ambition and practice. Eur. Environ. 14:94-104.

Corpade A.M., Corpade C., Petrea D., Moldovon C. 2012. Integrating environmental considerations into transportation planning through strategic environmental assessment. J. Settlements Spatial Plann. 3:115-20.

De Montis A. 2013. Implementing strategic environmental assessment of spatial planning tools. A study on the Italian Provinces. Environ. Impact Asses. 41:53-63.

De Montis A. 2014. Strategic environmental assessment of energy planning tools. A study of Italian regions and provinces. Environ. Impact Asses. 46:32-42.

De Montis A., Ledda A., Caschili S., Ganciu A., Barra M. 2014. SEA effectiveness for landscape and master planning: an investigation in Sardinia. Environ. Impact Asses. 47:1-13.

Diamantini C., Geneletti D. 2004. Reviewing the spplication of SEA sectoral plans in Italy. The case of the mobility plans of an Alpine region. Eur. Environ. 14:123-33.

European Commission. 1985. Council Directive on the assessment of the effects of certain public and private projects on the environment (85/337/EEC). In: Official Journal, L 175, 5/7/1985, pp 40-48.

European Commission. 1992. The future development of the common transport policy: a global approach to the construction of a community framework for sustainable mobility - white Paper. COM (92) 494 final, 2 December 1992. Bull. Eur. Commun. 3:1-73.

European Commission. 1999. DGII Transport. Manual on strategic environmental assessment of transport infrastructure plans; February 1999. Available from: http://www.ocs.polito.it/biblioteca/viavas/biblioteca/vas_trasporti.pdf Accessed: December 2014.

European Commission. 2001. Directive 2001/42/EC of the European Parliament and of the Council of 27 June 2001 on the assessment of the effects of certain plans and programmes on the environment. In: Official Journal, L 197, 21/7/2001, pp 30-37.
European Commission. 2004. Decision No. 884/2004/EC of the European Parliament and of the Council of 29 April 2004 amending Decision No. 1692/96/EC on Community guidelines for the development of the trans-European transport network. In: Official Journal, L 167, 7/6/2004, pp 1-55.

European Commission. 2005. DG TREN, The SEA manual, a sourcebook on strategic environmental assessment of transport infrastructure plans and programmes. Directorate B - Transeuropean Networks Energy \& Transport, Brussels. Available from: http:/ec.europa. eu/environment/archives/eia/sea-studies-and-reports/pdf/beacon_manuel_en.pdf

European Commission. 2009. Report from the Commission to the Council, the European Parliament, the European Economic and Social Committee and the Committee of the Regions on the application and effectiveness of the Directive on Strategic Environmental Assessment (Directive 2001/42/EC) Brussels, 14 September 2009, COM(2009) No. 469. Available from: http://eurlex.europa.eu/legal-content/EN/TXT/PDF/?uri=CELEX:52009 DC0469\&rid=1 Accessed: March 2014.

Finnveden G., Åkerman J. 2011. Not planning a sustainable transport system - Swedish case studies. pp 3509-16 in Proc. World Renewable Energy Congress, May 8-13, Linköping, Sweden.

Fischer T.B. 1999. Comparative analysis of environmental and socioeconomic impact in SEA for transport related policies, plans, and programs. Environ. Impact Asses. 19:275-303.

Fischer T.B. 2006. Strategic environmental assessment and transport planning: towards a generic framework for evaluating practice and developing guidance. Impact Assess. Proj. Apprais. 24:183-97.

Fischer T.B. 2010. Reviewing the quality of strategic environmental assessment reports for English spatial plan core strategies. Environ. Impact Asses. 30:62-9.

Fischer T.B. 2012. The quality of local transport plan (LTP) 3 SEA reports in North West England - A comparative review with English spatial and waste management planning related SEA practice. Town Country Plann. 81:281-6.

Fischer T.B., Gazzola P. 2006. SEA effectiveness criteria - equally valid in all countries? the case of Italy. Environ. Impact Asses. 26:396-409.

Fischer T.B., Potter K., Donaldson S., Scott T. 2011. Municipal waste management strategies, strategic environmental assessment and the consideration of climate change in England. J. Environ. Assess. Policy Manag. 13:541-65.

Gauthier M., Simard L., Waau J.P. 2011. Public participation in strategic environmental assessment (SEA): Critical review and the Quebec (Canada) approach. Environ. Impact. Asses. 31:48-60.

Hildén M., Furman E., Kaljonen M. 2004. Views on planning and expectations of SEA: the case of transport planning. Environ. Impact Asses. 24:519-36.

IAIA (International Association for Impact Assessment). 2002. Strategic environmental assessment performance criteria, IAIA special publication series, No. 1. International Association for Impact Assessment, Fargo, ND, USA.

Italian Regulation. 1981. Legge 10 aprile 1981, n. 151. Legge quadro per l'ordinamento, la ristrutturazione ed il potenziamento dei trasporti pubblici locali. Istituzione del Fondo nazionale per il ripiano dei disavanzi di esercizio e per gli investimenti nel settore. In: G.U., No. 113, 24/4/1981.

Italian Regulation. 1997. Decreto legislativo 19 novembre 1997, n. 422. Conferimento alle regioni ed agli enti locali di funzioni e compiti in materia di trasporto pubblico locale, a norma dell'articolo 4, comma 4, della legge 15 marzo 1997, n. 59. In: G.U., No. 287, $10 / 12 / 1997$.

Italian Regulation. 2001. Decreto del Presidente della Repubblica 14 marzo 2001. Nuovo piano generale dei trasporti e della logistica. In: 
G.U., n. 163, 16/7/2001. Available from: http://www.gazzettaufficiale.it/eli/id/2001/07/16/001A6017/sg

Italian Regulation. 2006. Decreto Legislativo 3 aprile 2006, no. 152. Norme in materia ambientale. In: G.U., No. 88, 14/4/2006. Available from: http:/www.camera.it/parlam/leggi/deleghe/06152dl2.htm

Italian Regulation. 2008. Decreto Legislativo 16 gennaio 2008, n. 4. Ulteriori disposizioni correttive ed integrative del decreto legislativo 3 aprile 2006, n. 152, recante norme in materia ambientale. In: G.U., No. 24, 29/1/2008. Available from: http://www.camera.it/parlam/leggi/deleghe/08004dl.htm

Italian Regulation, 2010. Decreto Legislativo 29 giugno 2010, n.128. Modifiche ed integrazioni al decreto legislativo 3 aprile 2006, n. 152 , recante norme in materia ambientale, a norma dell'articolo 12 della legge 18 giugno 2009, n. 69. In: G.U., No. 186, 11/8/2010. Available from: http://www.camera.it/parlam/leggi/deleghe/ 10128dl.htm

Jansson A.H.H. 1999. Strategic environmental assessment for transport in four nordic countries. pp 81-8 in Proc. 3rd Nordic EIA/SEA Conference, November 22-23, Karlskrona, Sweden.

Jiricka A., Pröbstl U. 2008. SEA in local land use planning - first experience in the Alpine States. Environ. Impact. Asses. 28:328-37.

Noble B.F. 2009. Promise and dismay: the state of strategic environmental assessment systems and practices in Canada. Environ. Impact Asses. 29:66-75.

Osservatorio Città Sostenibili (Strumenti di pianificazione dei trasporti). 2014. Torino: Osservatorio Città Sostenibili Dipartimento Interateneo Politecnico e Università di Torino. Available from: http://www.ocs.polito.it/mobilitatrasporti/strumenti.htm Accessed: March 2014.

Provincia Autonoma di Trento. 2004. Legge provinciale 15 dicembre 2004, n. 10 Disposizioni in materia di urbanistica, tutela dell'ambiente, acque pubbliche, trasporti, servizio antincendi, lavori pubblici e caccia. In: B.U., No. 50/bis, 17/12/2004. Available from: http://www.consiglio.provincia.tn.it/leggi-e-archivi/codice-provinciale/archivio/Pages/Legge\%20provinciale\%2015\%20dicembre\%20 2004,\%20n.\%2010_11773.aspx

Provincia Autonoma di Trento. 2008. Legge provinciale 4 marzo 2008, n. 1 Pianificazione urbanistica e governo del territorio. In: B.U., No. 11, 11/3/2008. Available from: http://www.consiglio.provincia.tn.it/ leggi-e-archivi/codice-provinciale/archivio/Pages/Legge\%20provinciale\%204\%20marzo\%202008,\%20n.\%201_17431.aspx

Provincia Autonoma di Trento. 2010. Piano stralcio della mobilità collegamento San Martino di Castrozza - Passo Rolle. Available from: http://www.lavoripubblici.provincia.tn.it/piani_mobilita/page20/pag e20.html Accessed: May 2014.

Regione Abruzzo. 2006. Legge regionale 9 agosto 2006, n. 27 Disposizioni in materia ambientale. In: B.U.R.A. No. 46, 30/8/2006. Available from: http://www.regione.abruzzo.it/xAutorita Amb/docs/chiSiamo/LR27_2006.pdf

Regione Abruzzo. 2010. Piano regionale integrato dei trasporti (PRIT). Available from: http://www.regione.abruzzo.it/trasporti/prit/ Accessed: May 2014.

Regione Puglia. 2012. Legge regionale 14 dicembre 2012, n. 44 Disciplina regionale in materia di valutazione ambientale strategica. In: B.U.R.A., No. 183, 18/12/2012. Available from: http://fesr.regione.puglia.it/portal/pls/portal/FESR.DYN_DOWNLOAD_APPENDICI.show?p_arg_names=id_appendice\&p_arg_values $=4032$

Regione Puglia. 2010. Piano regionale dei trasporti - Piano Attuativo 2009-2013. Available from: http://www.regione.puglia.it/index.php? page $=$ schede $\& i d=63$ Accessed: May 2014 .

Regione Emilia Romagna. 2000. Legge regionale 24 marzo 2000, n. 20 Disciplina generale sulla tutela e l'uso del territorio. In: B.U.R., No.
52, 24/3/2000. Available from: http://archivio.eddyburg.it/filemanager/download/1826/ER.LR.20.2000.a.dic.2009.pdf

Regione Emilia Romagna. 2008. Legge regionale 13 giugno 2008, n. 9 Disposizioni transitorie in materia di valutazione ambientale strategica e norme urgenti per l'applicazione del d.lgs. 3 aprile 2006, n. 152 In: B.U.R., No. 100, 13/6/2008.

Regione Emilia Romagna. 2012. PRIT - Piano regionale integrato dei trasporti. Available from: http://mobilita.regione.emiliaromagna.it/prit-piano-regionale-integrato-dei-trasporti Accessed: May 2014.

Regione Friuli Venezia Giulia. 2005. Legge regionale 6 maggio 2005, n. 11. Disposizioni per l'adempimento degli obblighi della Regione Friuli Venezia Giulia derivanti dall'appartenenza dell'Italia alle Comunità europee. Attuazione delle direttive 2001/42/CE, 2003/4/CE e 2003/78/CE (Legge comunitaria 2004). In: B.U.R., No. 19, 11/5/2005. Available from: http://lexview-int.regione.fvg.it/fontinormative/xml/xmllex.aspx?anno $=2005 \&$ legge $=11$

Regione Friuli Venezia Giulia. 2009. Legge regionale 30 luglio 2009, n. 13. Disposizioni per l'adempimento degli obblighi della Regione Friuli Venezia Giulia derivanti dall'appartenenza dell'Italia alle Comunità europee. Attuazione della direttiva 2006/123/CE. Attuazione dell'articolo 7 della direttiva 79/409/CEE concernente la conservazione degli uccelli selvatici. Attuazione del Regolamento (CE) n. 853/2004 in materia di igiene per gli alimenti di origine animale. Modifiche a leggi regionali in materia di sportello unico per le attività produttive, di interventi sociali e artigianato, di valutazione ambientale strategica (VAS), di concessioni del demanio pubblico marittimo, di cooperazione allo sviluppo, partenariato internazionale e programmazione comunitaria, di gestione faunistico-venatoria e tutela dell'ambiente naturale, di innovazione. (Legge comunitaria 2008). In: B.U.R., No. 31, 5/8/2009. Available from: https://lexview-int.regione.fvg.it/FontiNormative/xml /xmllex.aspx?anno=2009\&legge $=13$

Regione Friuli Venezia Giulia. 2011. Piano regionale delle infrastrutture di trasporto, della mobilità delle merci e della logistica. Available from: http://www.regione.fvg.it/rafvg/cms/RAFVG/infrastrutture-lavori-pubblici/infrastrutture-logistica-trasporti/ FOGLIA18 Accessed: May 2014.

Regione Lombardia. 2005. Legge regionale 11 marzo 2005, n. 12 Legge per il governo del territorio. In: B.U.R.L., No. 11, 16/3/2005. Available from: http://smtp.consiglio.regione.lombardia.it /NormeLombardia/Accessibile/main.aspx?view=showdoc\&iddoc=lr 002005031100012

Regione Lombardia. 2014. Piano regionale della mobilità ciclistica (PRMC). Available from: http://www.trasporti.regione. ombardia.it /cs/Satellite?c=Redazionale_P\&childpagename=DG_Infrastruttur e\%2FDetail\&cid=1213583146511\&pagename=DG_INFWrapper Accessed: May 2014.

Regione Marche. 2007. Legge regionale 12 giugno 2007, n. 6 Modifiche ed integrazioni alle leggi regionali 14 aprile 2004, n. 7, 5 agosto 1992, n. 34, 28 ottobre 1999, n. 28, 23 febbraio 2005, n. 16 e 17 maggio 1999, n. 10. Disposizioni in materia ambientale e Rete Natura 2000. In: B.U., No. 55, 21/6/2007. Available from: http://www.consiglio.marche.it/banche_dati_e_documentazione/leggirm/leggi/vis ualizza/vig/1535

Regione Marche. 2011. Piano regionale del T.P.L. 2009-2019. Available from: http://www.trasporti.marche.it/nuke/downloads.asp?cat=211 Accessed: February 2014.

Regione Piemonte. 1998. Legge regionale 14 dicembre 1998, n. 40 Disposizioni concernenti la compatibilità ambientale e le procedure di valutazione. In: B.U., No. 50, 17/12/1998. Available from: http://www.regione.piemonte.it/ambiente/valutazioni_ambientali/d wd/balmuccia/01_Elenco_Autorizzazioni.pdf 
Regione Piemonte, 2010. Piano regionale per la logistica. http://www.regione.piemonte.it/trasporti/dwd/prl_ver_15dic09.pdf Accessed: May 2014.

Sheate W.R. 1992. Strategic environmental assessment in the transport sector. Proj. Apprais. 7:170-4.

Tomlinson P. 2011. SEA and transport planning. In: B. Sadler, J. Dusik, T.B. Fischer, M.R. Partidário, R. Verheem, R. Aschemann (Eds.), Handbook of strategic environmental assessment. Earthscan
Publications Ltd, London and Washington, DC, pp 177-89.

van Buuren A., Nooteboom S. 2010. The success of SEA in the Dutch planning practice. How formal assessments can contribute to collaborative governance. Environ. Impact Asses. 30:127-35.

van Doren D., Driessen P.P.J., Schijf B., Runhaar H.A.C. 2013. Evaluating the substantive effectiveness of SEA: towards a better understanding. Environ. Impact Asses. 38:120-30. 